\title{
Hepatitis B Virus Core IgM Antibody Measurement
}

National Cancer Institute

\section{Source}

National Cancer Institute. Hepatitis B Virus Core IgM Antibody Measurement. NCI

Thesaurus. Code C96661.

The determination of the amount of Hepatitis B virus core Ig M antibody present in a sample. 